\title{
Sintesis Dan Karakterisasi Komposit Magnetik Lempung Putih Asal Kalimantan Tengah Sebagai Adsorben Zat Warna Pada Limbah Cair
}

\author{
Karelius*, Nopriawan Berkat Asi \\ Program Studi Pendidikan Kimia, Universitas Palangka Raya, Palangka Raya, Indonesia
}

\begin{abstract}
Abstrak : Sintesis, karakterisasi dan uji adsorpsi komposit magnetik lempung putih asal Kalimantan Tengah terhadap warna zat warna pada limbah cair telah dilakukan. Sintesis komposit magnetik lempung putih dilakukan dengan metode kopresipitasi. Karakterisasi komposit magnetik lempung putih dilakukan dengan spektroskopi FTIR (Fourier Transform Infrared), XRD (X-ray diffraction) dan VSM (Vibrating sample magnetometer). Uji adsorpsi dilakukan menggunakan sistem batch dengan kajian adsorpsi yang dipelajari meliputi $\mathrm{pH}$ optimum, kinetika adsorpsi dan kesetimbangan adsorpsi. Hasil penelitian menunjukkan bahwa metode kopresipitasi telah berhasil mengkompositkan oksida besi fasa magnetit pada lempung putih asal Kalimantan Tengah dengan nilai magnetisasi sebesar 21,38 emu/g. Lempung putih, lempung putih teraktivasi dan komposit magnetik lempung putih mampu mengadsorpsi Zat warna pada limbah cair dari dalam larutan dengan adsorpsi maksimal secara berturut-turut terjadi pada $\mathrm{pH} \mathrm{3,} 3$ dan 2. Kajian kinetika dan kesetimbangan adsorpsi menunjukkan bahwa adsorpsi Zat warna pada limbah cair oleh ketiga jenis adsorben mengikuti kinetika orde dua semu dengan pola isoterm Langmuir. Komposit magnetik lempung putih asal Kalimantan Tengah mampu meningkatkan kapasitas adsorpsi Zat warna pada limbah cair sampai dengan 2 kali lipatnya dan dapat mempercepat proses pemisahan partikel adsorben dari dalam larutan menggunakan medan magnet eksternal.
\end{abstract}

\section{Kata kunci : magnetit, kopresipitasi, adsorpsi dan Zat warna pada limbah cair}

\section{Pendahuluan}

Lempung merupakan mineral alam dari keluaraga silikat yang berbentuk kristal dengan struktur berlapis, memiliki ukuran partikel lebih kecil dari $2 \mathrm{m \mu}$, mudah dibentuk dalam keadaan basah dan mengeras dengan warna kemerahmerahan jika dibakar (Ortega et al., 2013). Kalimantan Tengah merupakan salah satu provinsi yang memiliki cadangan lempung cukup besar yaitu sekitar 8.900.352.000 $\mathrm{m}^{3}$. Tersebar di beberapa lokasi, seperti di Kota Palangka Raya, Kabupaten Barito Selatan, Barito Utara dan Gunung Mas (Amarullah et al., 2002). Kekayaan alam yang cukup melimpah ini merupakan salah satu aset potensial Kalimantan Tengah yang harus dimanfaatkan sebaik-baiknya.

Salah satu jenis lempung alam asal Kalimantan Tengah yang banyak ditemukan adalah lempung putih. Lempung merupakan material alam yang memiliki beberapa kelebihan, yakni sifat mudah mengembang, kapasitas tukar kation yang tinggi, luas permukaan yang besar dan stabil secara kimia dan mekanika (Ortega et al., 2013). Kelebihan-kelebihan tersebut menjadikan bahan ini banyak dimanfaatkan sebagai adsorben untuk adsorpsi kontaminan air, seperti ion $\mathrm{Pb}$ (II) (Widihati, 2009), Cd(II)-Ni(II) (Ortega et al., 2013), Cu(II) dan $\mathrm{Zn}$ (II) (Musso et al., 2014), Cr(VI) (Zhao et al., 2015), limbah uranium (Sunardi et al., 2011), ion posfat (Sinta et al., 2015), zat warna methylene blue (Elmoubarki et al., 
2014), malachite green, brilliant green (Rehman et al., 2013), basic red 46 dan direct blue 85 dalam larutan (Santos et al., 2016).

Sebelum digunakan sebagai adsorben, lempung putih harus diaktivasi untuk melepaskan pengotor-pengotor dari kisi struktur sehingga secara fisik rangkaian struktur (framework) memiliki area yang lebih luas. Aktivasi dilakukan melalui dua cara, yaitu aktivasi secara kimia dan fisis. Proses aktivasi secara kimia dilakukan dengan menggunakan larutan asam dan aktivasi secara fisis dilakukan dengan pemanasan (kalsinasi) (Koyuncu, 2007).

Penggunaan lempung sebagai adsorben memiliki kesulitan dalam proses pemisahan fase padat adsorben dalam larutan setelah proses adsorpsi (Hamsah, 2007). Salah satu upaya yang dapat dilakukan untuk mengatasi kesulitan tersebut ialah dengan mengkompositkan lempung putih dengan bahan magnetik sehingga diperoleh komposit magnetik lempung yang memiliki sifat kemagnetan.

Sintesis komposit diharapkan dapat menghasilkan bahan baru yang mempunyai dua sifat utama yaitu, sifat adsorpsi yang berasal dari lempung dan sifat magnet yang berasal dari bahan magnetik yang terkomposit didalam jaringan struktur lempung. Sifat adsorpsi yang dimiliki digunakan untuk menyerap kontaminan air sedangkan sifat magnet yang diperoleh digunakan untuk mempermudah proses pemisahan adsorben setelah proses adsorpsi menggunakan medan magnet eksternal (Oliveira et al., 2003).

Salah satu jenis bahan magnetik yang dapat dikompositkan pada lempung putih adalah oksida besi fasa magnetit $\left(\mathrm{Fe}_{3} \mathrm{O}_{4}\right)$. Fasa ini membentuk keteraturan ferimagnetik dengan nilai magnetisasi saturasi (Ms) tertinggi yaitu sebesar 92 emu/g. Sintesis komposit magnetik dapat dilakukan melalui metode kopresipitasi. Keserbagunaan dan kesederhanaan metode kopresipitasi menjadikan metode ini lebih disukai (Lee et al, 2004).

Salah satu contoh zat warna yang banyak digunakan pada industri tekstil adalah Zat warna pada limbah cair. Dalam proses pewarnaan, senyawa ini hanya tergunakan sekitar 5\% sedangkan 95\% sisanya akan dibuang kealiran air sebagai limbah (Purwamargapratala et al., 2013). Jika pemanfaatan zat warna tidak diimbangi dengan penanggulangan limbah yang dihasilkan, maka akan sangat berdampak pada munculnya berbagai permasalahan lingkungan dan kesehatan, karena sifatnya yang toksik, stabil dan non-degradable (Purwamargapratala et al., 2013).

Atas pertimbangan tersebut di atas dan untuk memperoleh adsorben yang cukup efisien ditinjau dari kelimpahan dan kemampuannya, maka pada penelitian ini akan dilakukan "Sintesis dan Karakterisasi Komposit Magnetik Lempung putih asal Kalimantan Tengah sebagai Adsorben Zat Warna Zat warna pada limbah cair". Melalui penelitian ini diharapkan dapat meningkatkan nilai ekonomis lempung sebagai salah satu potensi alam Kalimantan Tengah dengan kelimpahan cukup besar dan menghasilkan teknologi tepat guna untuk mengatasi masalah pencemaran zat warna di wilayah Kalimantan Tengah. 
Jurnal Ilmiah Kanderang Tingang 9(1) (2018) 51-66

ISSN 2087-166X

Januari-Juni 2018
Fakultas Keguruan dan Ilmu Pendidikan

Universitas Palangka Raya

Email:info@chem.upr.ac.id Web:www.chem-upr.education/ojs

\section{Metode}

\section{Persiapan sampel}

Lempung putih asal Kalimantan Tengah yang diperoleh dari kota Palangka Raya dibersihkan dari pengotor kasar, kemudian dioven pada temperatur $70^{\circ} \mathrm{C}$ selama 3 jam. Selanjutnya dilakukan penggerusan dan diayak dengan menggunakan ayakan lolos 60 mesh. Produk lempung putih hasil persiapan (LKM) selanjutnya dikarakterisasi menggunakan instrumen FTIR dan XRD.

\section{Aktivasi Lempung Alam}

Sebanyak 50 gram lempung putih (LK-M) yang telah diayak, direfluks dengan $250 \mathrm{~mL} \mathrm{HCl} 3 \mathrm{M}$ selama 3 jam pada temperatur $100^{\circ} \mathrm{C}$. Kemudian disaring dan dicuci dengan akuades hingga lolos uji klor menggunakan $\mathrm{AgNO}_{3}$ 0,1 M. Padatan dikeringkan dalam oven pada temperatur $100^{\circ} \mathrm{C}$ selama $3 \mathrm{jam}$, digerus dan diayak dengan menggunakan ayakan lolos 60 mesh. Lempung yang telah diaktivasi dengan larutan asam selanjutnya dikalsinasi menggunakan furnace pada temperatur $500^{\circ} \mathrm{C}$ selama 3 jam. Produk lempung putih hasil aktivasi (LK-A) selanjutnya dikarakterisasi menggunakan instrumen FTIR dan XRD.

\section{Sintesis Komposit Magnetik Lempung putih}

Larutan $\mathrm{Fe}^{2+}$ dan $\mathrm{Fe}^{3+}$ dibuat dalam volume $100 \mathrm{~mL}$ dengan konsentrasi masing-masing sebesar 0,025 $\mathrm{M}$ dan 0,05 M. Kedua larutan dimasukan ke dalam gelas beker $500 \mathrm{~mL}$ yang di dalamnya terdapat 2 gram lempung putih hasil aktivasi (LK-A). Campuran diaduk pada temperatur $85^{\circ} \mathrm{C}$, kemudian ditambahkan larutan $\mathrm{NH}_{4} \mathrm{OH}$ tetes demi tetes hingga $\mathrm{pH}$ mencapai 10. Campuran didinginkan selama 3 jam kemudian koloid yang terbentuk dipisahkan dari larutan menggunakan medan magnet eksternal. Padatan dicuci menggunakan akuades dan dioven pada temperatur $110^{\circ} \mathrm{C}$ selama 2 jam, selanjutnya digerus perlahan-lahan sampai diperoleh bubuk halus. Produk komposit magnetik lempung putih (LK-K) selanjutnya dikarakterisasi menggunakan instrumen FTIR dan XRD dan VSM.

\section{Uji Adsorpsi}

\section{a. Penentuan pH Optimum}

Sebanyak 0,05 gram sampel LK-M, LK-A dan LK-K digunakan untuk mengadsorpsi $50 \mathrm{~mL}$ larutan Zat warna pada limbah cair $50 \mathrm{ppm}$ dengan $\mathrm{pH}$ awal 1, 2, 3, 4, 5 dan 6. Proses dilakukan menggunakan shaker selama 3 jam pada temperatur kamar. Konsentrasi Zat warna pada limbah cair yang tidak teradsorpsi diukur dengan menggunakan Spektrofotometer UV-Vis.

\section{b. Kinetika Adsorpsi}

Sebanyak 0,05 gram sampel LK-M, LK-A dan LK-K digunakan untuk mengadsorpsi $50 \mathrm{~mL}$ larutan Zat warna pada limbah cair $50 \mathrm{ppm}$ pada $\mathrm{pH}$ optimum dengan variasi waktu 5, 10, 20, 40, 60, 90, 180, 300 dan 420 menit pada 
temperatur kamar. Konsentrasi Zat warna pada limbah cair yang tidak teradsorpsi diukur dengan menggunakan Spektrofotometer UV-Vis.

\section{c. Kesetimbangan Adsorpsi}

Sebanyak 0,05 gram sampel LK-M, LK-A dan LK-K digunakan untuk mengadsorpsi $50 \mathrm{~mL}$ larutan Zat warna pada limbah cair pada $\mathrm{pH}$ dan waktu optimum dengan variasi konsentrasi 10, 20, 30, 40 dan 50 ppm pada temperatur kamar. Konsentrasi Zat warna pada limbah cair yang tidak teradsorpsi diukur dengan menggunakan Spektrofotometer UV-Vis.

\section{Uji pemisahan adsorben dalam larutan zat warna pada limbah cair}

Larutan Zat warna pada limbah cair $50 \mathrm{~mL}$ masing-masing dimasukan pada 2 buah botol sampel. Kemudian masing-masing botol sampel ditambahkan dengan adsorben LK-A dan LK-K, di shaker selama 60 menit dan didiamkan beberapa saat. Botol sampel yang terdapat adsorben LK-K diberi medan magnet eksternal. Kemudian diamati apa yang terjadi pada masing-masing campuran.

\section{Hasil Dan Pembahasan}

\section{Sintesis dan Karakterisasi Komposit Magnetik Lempung putih}

Lempung putih asal Kalimantan Tengah diaktivasi terlebih dahulu sebelum digunakan pada tahap sintesis. Aktivasi dilakukan dengan dua cara yaitu aktivasi secara kimia dan aktivasi secara fisis.

Aktivasi secara kimia dilakukan dengan merefluks lempung putih dengan larutan $\mathrm{HCl} 3 \mathrm{M}$ pada temperatur $105^{\circ} \mathrm{C}$ selama 3 jam untuk melarutkan pengotor dan menukarkan kation penyeimbang pada jaringan struktur lempung dengan ion $\mathrm{H}^{+}$agar secara fisik rangkaian struktur (framework) memiliki area yang lebih luas sehingga dimungkinkan suatu ion atau molekul dapat masuk ke jaringan struktur lempung dengan lebih baik (Benguella and Yacouta, 2007).

Sedangkan aktivasi secara fisis dilakukan dengan pemanasan (kalsinasi). Kalsinasi dilakukan pada temperatur $500^{\circ} \mathrm{C}$ selama 3 jam untuk eliminasi gas atau senyawa organik yang mempunyai ikatan kimia dengan lempung serta hidrasi molekul air yang masih terperangkap pada kisi kristal mineral lempung sehingga luas permukaan spesifik lempung menjadi bertambah (Koyuncu, 2008).

Sintesis komposit magnetik lempung putih dilakukan dengan mereaksikan lempung putih dengan larutan $\mathrm{Fe}^{2+}$ dan $\mathrm{Fe}^{3+}$ pada rasio mol $1: 2$ pada temperatur $85^{\circ} \mathrm{C}$. Ion-ion $\mathrm{Fe}^{2+}$ dan $\mathrm{Fe}^{3+}$ kemudian akan masuk ke dalam jaringan struktur lempung putih yang terjadi melalui proses pertukaran ion atau terjerap pada permukaan lempung putih yang bermuatan negatif. Muatan negatif dihasilkan dari substitusi isomorfik mineral lempung.

Menurut Notodarmojo (2005), pertukaran kation salah satunya dipengaruhi oleh muatan ion. Muatan ion yang besar cenderung menggantikan ion dengan muatan yang lebih kecil. $\mathrm{Fe}^{3+}$ memiliki muatan yang lebih besar jika 
dibandingkan dengan kation $\mathrm{H}^{+}$yang terdapat di jaringan struktur lempung teraktivasi sehingga $\mathrm{Fe}^{3+}$ dapat dengan mudah menggantikan kation-kation tersebut. Demikian pula dengan ion $\mathrm{Fe}^{2+}$ yang dapat mengalami pertukaran ion atau menempel pada permukaan lempung yang bermuatan negatif. $\mathrm{Fe}^{2+}$ dan $\mathrm{Fe}^{3+}$ selanjutnya akan mengalami kopresipitasi membentuk $\mathrm{Fe}(\mathrm{OH})_{2}$ dan $\mathrm{Fe}(\mathrm{OH})_{3}$ ketika ditambahkan larutan $\mathrm{NH}_{4} \mathrm{OH}$. Setelah mengalami pemanasan, $\mathrm{Fe}(\mathrm{OH})_{2}$ dan $\mathrm{Fe}(\mathrm{OH})_{3}$ teroksidasi menjadi magnetit $\left(\mathrm{Fe}_{3} \mathrm{O}_{4}\right)$ sehingga dihasilkan komposit magnetik lempung putih yang memiliki sifat kemagnetan.

Hasil aktivasi lempung putih dan sintesis komposit magnetik lempung putih asal Kalimantan Tengah kemudian akan diverifikasi karakteristiknya menggunakan instrumen Fourier-Transform Infrared (FTIR) dan X-Ray Diffraction (XRD). Data FTIR digunakan untuk memperoleh informasi mengenai gugus fungsi yang terdapat pada sampel sedangkan data XRD digunakan untuk mengkonfirmasi komposisi mineral penyusun sampel secara kualitatif dan semikuantitatif.

Gambar 1 menyajikan data spektra hasil analisis menggunakan spekroskopi FTIR. Gambar 1(a) merupakan spektrum inframerah sampel lempung putih sebelum aktivasi (LK-M). Spektrum tersebut memperlihatkan adanya beberapa puncak serapan yang cukup tajam, yaitu pada daerah bilangan gelombang 3691,48; 3436,90; 1662,52; 999,05 902,62 dan 686,61 $\mathrm{cm}^{-1}$. Puncak daerah bilangan gelombang $3436,90 \mathrm{~cm}^{-1}$ dan $1662,52 \mathrm{~cm}^{-1}$ secara berturut-turut merupakan puncak serapan dari vibrasi ulur $-\mathrm{OH}$ dan vibrasi tekuk $-\mathrm{OH}$ dari molekul air yang terperangkap dalam kisi kristal lempung putih (Wang et al., 2011). Sedangkan pada daerah bilangan gelombang $3691,48 \mathrm{~cm}^{-1}$ menunjukan adanya vibrasi ulur $-\mathrm{OH}$ yang memiliki perbedaan lingkungan, yaitu $-\mathrm{OH}$ yang terikat pada atom Al oktahedral yang terdapat pada permukaan silikat atau pada antar lapis silikat dari struktur mineral lempung. Pita serapan tersebut berkorelasi dengan adanya bilangan gelombang 902,62 yang menunjukan adanya vibrasi tekuk Al-OH (Eren et al., 2009).

Puncak serapan yang tajam pada daerah sekitar 999,05 $\mathrm{cm}^{-1}$ merupakan serapan karakteristik dari vibrasi ulur Si-O (Eren et al., 2009). Serapan kuat pada daerah 950-1250 $\mathrm{cm}^{-1}$ adalah vibrasi ulur dari $\mathrm{M}-\mathrm{O}$ (dimana $\mathrm{M}=\mathrm{Si}$ atau $\mathrm{Al}$ ) yang melibatkan gerak utama dari atom oksigen Si-O. Data ini berkorelasi dengan bilangan gelombang $686,61 \mathrm{~cm}^{-1}$ yang karakteristik dengan vibrasi ulur Si-O. Sedangkan pita serapan pada daerah $794,61 \mathrm{~cm}^{-1}$ menunjukan adanya vibrasi ulur dari O-Si-O yang karakteristik terhadap mikrokristalin $\mathrm{SiO}_{2}$ atau lebih dikenal dengan mineral kuarsa (Holtzer et al., 2011; Hajjaji dan Arfaoui, 2009). Dengan demikian, berdasarkan seluruh data puncak-puncak serapan tersebut diperoleh informasi bahwa sampel yang dianalisis merupakan keluarga dari mineral silika alumina. 


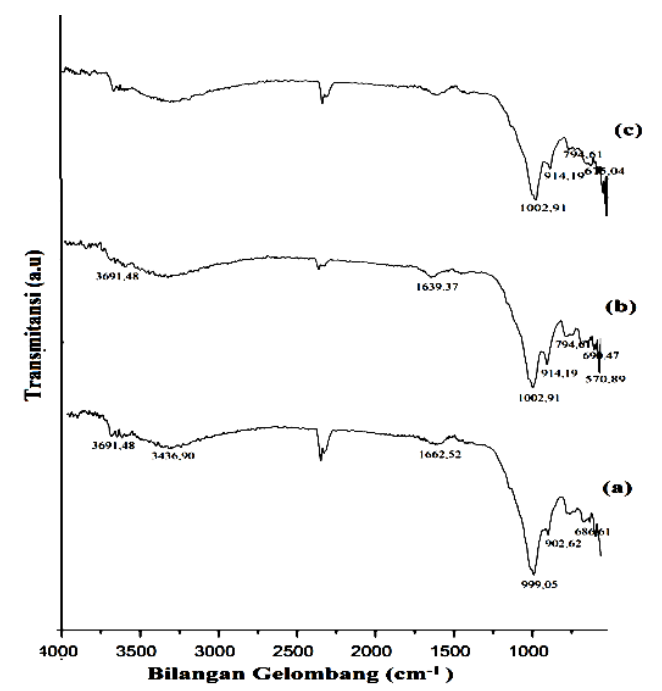

\section{Gambar 1. Spektra FTIR : (a) LK-M; (b) LK-A dan (c) LK-K}

Pola spektra FTIR sampel lempung putih (LK-M) sebelum dan sesudah aktivasi (LK-A) sebagaimana ditunjukan pada Gambar 1(a) dan 1(b) secara keseluruhan tidak menunjukkan perubahan yang signifikan. Hal ini mengindikasikan bahwa aktivasi secara kimia dan fisis, struktur lempung tidak mengalami kerusakan berdasarkan eksistensi gugus fungsi. Sedikit pergeseran spektrum terjadi pada daerah bilangan gelombang $999,05 \mathrm{~cm}^{-1}$ yang menunjukan adanya vibrasi ulur dari Si-O mengalami pergeseran ke arah bilangan gelombang $1002,91 \mathrm{~cm}^{-1}$. Pergeseran kearah bilangan gelombang yang lebih besar mengindikasikan bahwa terjadi dealuminasi pada struktur kristal mineral lempung. Proses aktivasi memungkinkan terjadi pengurangan atom Al pada kerangka struktur lempung. Hal ini dikarenakan kekuatan ikatan Al-O jauh lebih lemah jika dibandingkan dengan ikatan Si-O, dengan berkurangnya ikatan Al-O menyebabkan vibrasi Si-O menjadi lebih dominan sehingga terjadi pergeseran bilangan gelombang ke arah yang lebih besar (Holtzer et al., 2011).

Bilangan gelombang $902,62 \mathrm{~cm}^{-1}$ yang menunjukan adanya vibrasi tekuk Al-OH yang mengalami pergeseran ke arah bilangan gelombang lebih besar, yaitu sebesar 914,19 $\mathrm{cm}^{-1}$ mengindikasikan bahwa semakin homogennya lingkungan dari struktur Al-OH akibat adanya disolusi atom-atom logam di luar kerangka mineral lempung (non-oktahedral) (Saikia et al., 2003). Hal tersebut merupakan salah satu indikasi yang menunjukkan bahwa proses aktivasi kimia dengan perlakuan asam mampu menghilangkan pengotor yang masih terperangkap pada kisi kristal mineral lempung putih.

Bilangan gelombang $1662,52 \mathrm{~cm}^{-1}$ menunjukan adanya vibrasi tekuk $-\mathrm{OH}$ dari molekul air yang terperangkap dalam kisi kristal lempung putih mengalami pergeseran ke arah bilangan gelombang lebih kecil, yaitu sebesar 1639,37 $\mathrm{cm}^{-1}$ yang menunjukan bahwa terjadi hidrasi molekul air yang terperangkap pada kisi kristal lempung setelah mengalami aktivasi. Hal tersebut merupakan salah satu indikasi yang menunjukkan bahwa proses aktivasi fisis dengan kalsinasi mampu 
menghidrasi molekul air yang masih terperangkap pada kisi kristal mineral lempung putih sehingga luas permukaan spesifik lempung putih menjadi bertambah.

Pola spektra inframerah sampel lempung putih teraktivasi (LK-A) dan komposit magnetik lempung putih (LK-K) yang ditunjukkan pada Gambar 1(b) dan 1(c) memperlihatkan adanya perubahan, seperti pada pita serapan $690,47 \mathrm{~cm}^{-1}$ mengalami pergeseran kearah bilangan gelombang yang lebih kecil, yaitu sebesar $675,04 \mathrm{~cm}^{-1}$ yang menunjukan menunjukan bahwa vibrasi Si-O dalam keadaan kurang bebas. Data ini juga didukung dengan bentuk spektrum pada bilangan gelombang 400-500 $\mathrm{cm}^{-1}$ yang lebih landai bila dibandingkan dengan data spektrum LK-A.

Hal tersebut menunjukan bahwa kekuatan ikatan tekuk Si-O berkurang karena terdapatnya ikatan-ikatan antara oksigen dengan Fe yang berasal dari oksida besi yang memberikan kompetisi kekuatan ikatan tarik menarik antara Si-O-Fe (Ardianto, 2013).

Untuk memperkuat hasil identifikasi diperlukan data pendukung berupa data XRD untuk mengetahui mineral penyusun lempung putih dan fasa oksida besi yang terkomposit didalam jaringan struktur lempung putih. Difraktogram sinar- $x$ untuk ketiga sampel ditunjukkan pada Gambar 2.

Berdasarkan standar yang dikeluarkan oleh Joint Comitte on Powder Difraction (JCPDS) dapat dinyatakan bahwa sampel lempung putih (LK-M) yang digunakan pada penelitian ini mengandung mineral halosit $\left(\left(\mathrm{Si}_{4}\right)^{\mathrm{VI}}\left(\mathrm{Al}_{4}\right)^{\mathrm{VI}} \mathrm{O}_{10}(\mathrm{OH})_{8}\right)$, monmorilo nit $\left(\left(\mathrm{Si}_{7,8} \mathrm{Al}_{0,2}\right)^{\mathrm{IV}}\left(\mathrm{Al}_{3,4} \mathrm{Mg}_{0,6}\right)^{\mathrm{VI}} \mathrm{O}_{20}(\mathrm{OH})_{4}\right)$, kuarsa $\left(\mathrm{SiO}_{2}\right)$, calcite $\left(\mathrm{CaCO}_{3}\right)$, oligoclase $\left((\mathrm{Na}, \mathrm{Ca}) \mathrm{Al}(\mathrm{Al}, \mathrm{Si}) \mathrm{Si}_{2} \mathrm{O}_{8}\right)$ dan biotite $\left.\left(\mathrm{K}(\mathrm{Mg}, \mathrm{Fe})_{3}(\mathrm{Al}, \mathrm{Fe}) \mathrm{Si}_{3} \mathrm{O}_{10}(\mathrm{OH}, \mathrm{F})_{2}\right)\right)$.

Data XRD pada gambar 2(a) dan 2(b) memperlihatkan adanya perubahan yang cukup jelas pada pucak halosit di $2 \theta=12,09^{\circ}$ setelah aktivasi menghilang, kemudian pada puncak calcite di $2 \theta=40,05^{\circ}$ dan $49,92^{\circ}$ serta puncak biotite di $2 \theta$ $=59,69^{\circ}$ mengalami penurunan intensitas. Hal ini mengindikasikan bahwa aktivasi menyebabkan kerusakan pada struktur mineral halosit, calcite dan biotite yang merupakan mineral pengotor penyusun lempung putih. 


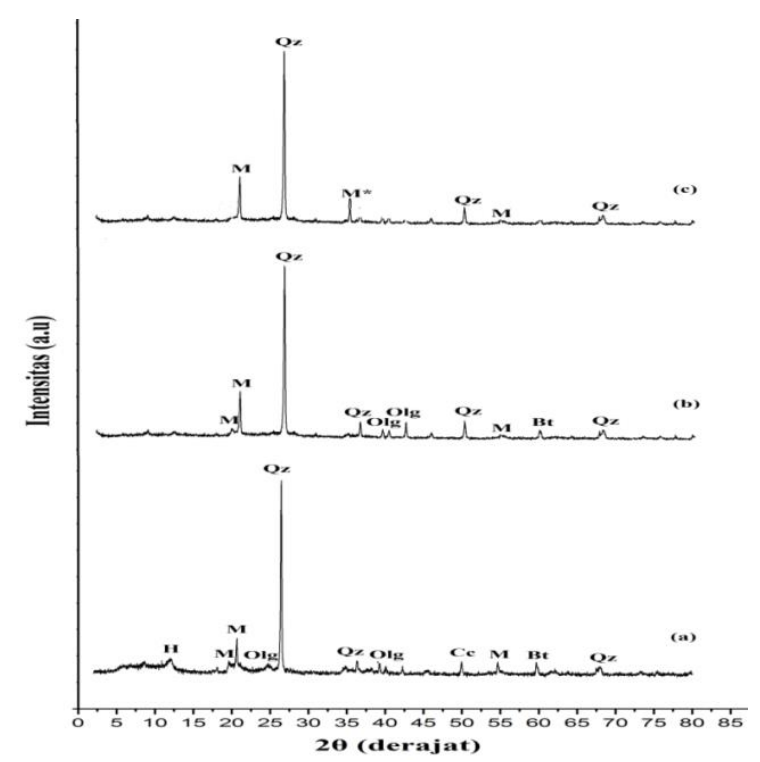

Gambar 2. Difraktogram sinar $x$ (a) LK-M; (b) LK-A dan (c) LK-K (M = monmorilonit, $\mathrm{Qz}=$ kuarsa, $\mathrm{Olg}=$ oligoclase, $\mathrm{Cc}=$ calcite, $\mathrm{Bt}=$ biotite, $\mathrm{M}^{*}=$ magnetit)

Data kualitatif yang diperoleh dari data XRD diatas juga didukung dengan data semikuantitatif yang disajikan pada Tabel 1. Terlihat bahwa aktivasi mampu meningkatkan komposisi relatif dari mineral monmorilonit, oligoclase dan kuarsa, serta menurunkan kelimpahan relatif dari mineral halosit, calcite dan biotite yang merupakan mineral pengotor lempung putih.

Difraktogram Gambar 2(c) juga memperlihatkan perubahan pola difraksi pada komposit magnetik lempung putih dengan munculnya puncak baru berdasarkan standar yang dikeluarkan oleh Joint Comitte on Powder Difraction (JCPDS) yaitu pada $2 \theta$ sebesar $35,35^{\circ}$ yang berkesesuaian dengan $\mathrm{d}=2,54 \AA$. Puncak difraktogram tersebut karakteristik terhadap oksida besi fasa magnetit $\left(\mathrm{Fe}_{3} \mathrm{O}_{4}\right)$. Hal ini mengindikasikan bahwa oksida besi yang terkomposit di dalam jaringan struktur lempung putih adalah oksida besis fasa magnetit $\left(\mathrm{Fe}_{3} \mathrm{O}_{4}\right)$.

Tabel 1. Analisis semikuantitatif sampel dihitung berdasarkan data XRD

\begin{tabular}{cccccccc}
\hline \multirow{2}{*}{ Sampel } & \multicolumn{7}{c}{ Komposisi relatif mineral ( \% ) } \\
\cline { 2 - 9 } & Monmorilonit & Halosit & Kuarsa & Calcite & Biotite & Oligoclase & Magnetit \\
\hline LK-M & 23,73 & 9,39 & 53,54 & 4,93 & 3,71 & 4,70 & - \\
LK-A & 24,41 & - & 64,39 & 2,24 & 3,13 & 5,83 & - \\
LK-K & 12,89 & - & 62,57 & - & - & - & 24,54 \\
\hline
\end{tabular}

Pengamatan visual warna padatan komposit magnetit lempung putih yang dihasilkan pada penelitian ini juga dapat menunjukkan jenis oksida besi yang terbentuk. Perbedaan warna padatan yang dihasilkan disajikan pada Gambar 3. Komposit magnetik lempung putih yang dihasilkan berwarna hitam. Hal ini disebabkan karena di dalam sampel terdapat magnetit, dimana jenis oksida besi yang berwarna hitam adalah oksida besi fasa magnetit $\left(\mathrm{Fe}_{3} \mathrm{O}_{4}\right)$. 
Jurnal Ilmiah Kanderang Tingang 9(1) (2018) 5l-66 ISSN 2087-166X

Januari-Juni 2018

Fakultas Keguruan dan Ilmu Pendidikan

Universitas Palangka Raya

Email:info@chem.upr.ac.id Web:www.chem-upr.education/ojs

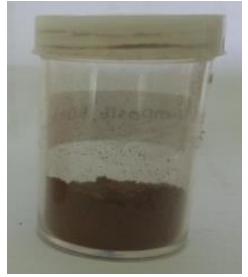

b

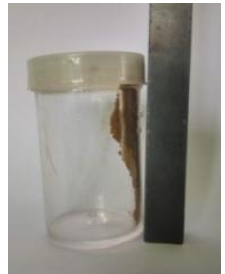

c

Gambar 3. (a) LK-A, (b) LK-K dan (c) uji coba LK-K dengan magnet eksternal

Berdasarkan Gambar 3(c) diketahui bahwa sintesis komposit magnetik lempung putih dengan metode kopresipitasi telah berhasil dilakukan. Komposit magnetik lempung putih memiliki sifat kemagnetan yang terlihat dari gambar merespon medan mangnet eksternal. Pemberian sifat kemagnetan ini bertujuan untuk memudahkan proses pemisahan adsorben dari dalam larutan menggunakan medan magnet eksternal setelah uji adsorpsi. Nilai magnetisasi komposit lempung putih yang dihasilkan dapat dianalisis dengan menggunakan instrumen Vibrating sample magnetometer (VSM).

Hasil pengujian nilai magnetisasi komposit magnetik lempung putih menggunkan VSM ditampilan dalam bentuk kurva histeresis seperti ditunjukan pada Gambar 4 berikut. Komposit magnetik yang terbentuk menunjukan perilaku superparamagnetik dengan nilai magnetisasi sebesar 21,38 emu/g.



\section{Gambar 4. Kurva histeresis LK-K}

\section{Uji Adsorpsi terhadap Zat warna pada limbah cair}

Uji adsorpsi dilakukan pada sampel LK-M, LK-A dan LK-K terhadap zat warna Zat warna pada limbah cair dilakukan dengan menggunakan sistem batch melalui 3 tahapan, yaitu penentuan $\mathrm{pH}$ optimum, kinetika adsorpsi dan kapasitas adsorpsi.

\section{Penentuan pH Optimum}

Adapun hasil kajian pengaruh $\mathrm{pH}$ terhadap adsorpsi zat warna pada limbah cair pada kedua jenis adsorben dapat dilihat pada Gambar 5. 
Jurnal Ilmiah Kanderang Tingang 9(1) (2018) 51-66 ISSN 2087-166X

Januari-Juni 2018
Fakultas Keguruan dan Ilmu Pendidikan

Universitas Palangka Raya

Email:info@chem.upr.ac.id Web:www.chem-upr.education/ojs

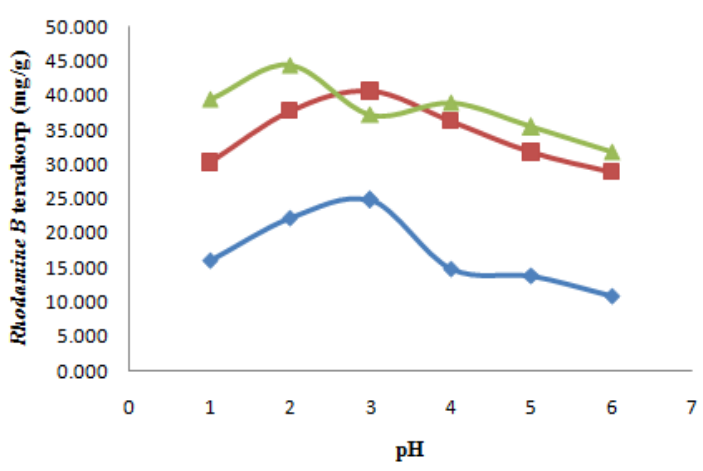

Gambar 5. Adsorpsi Zat warna pada limbah cair sebagai fungsi pH

Berdasarkan Gambar 5, kemampuan adsorpsi dari ketiga jenis adsorben memiliki pola yang hampir sama. Terlihat bahwa adsorpsi Zat warna pada limbah cair oleh lempung putih tanpa aktivasi (LK-M) optimum terjadi pada $\mathrm{pH} \mathrm{3,}$ lempung putih teraktivasi (LK-A) pada $\mathrm{pH} 3$ dan komposit magnetik lempung putih (LK-K) pada $\mathrm{pH}$ 2. Penentuan $\mathrm{pH}$ optimum merupakan salah satu parameter penting dalam mengontrol proses adsorpsi. Harga $\mathrm{pH}$ larutan dapat mempengaruhi muatan permukaan adsorben dan spesiesi adsorbat.

Mineral monmorilonit dalam lempung putih merupakan jenis mineral silika alumina yang dapat digunakan sebagai adsorben. Hal ini disebabkan karena mineral monmorilonit memiliki situs aktif permanen yang bermuatan negatif. Muatan negatif ini dibentuk dari peristiwa substitusi isomorfik, yaitu substitusi $\mathrm{Si}^{4+}$ dengan $\mathrm{Al}^{3+}$ pada lapisan tetrahedral dan substitusi $\mathrm{Al}^{3+}$ dengan $\mathrm{Mg}^{2+}$ pada lapisan oktahedral. Bagian inilah yang disebut sebagai situs aktif (active site) lempung putih yang dapat digunakan sebagai adsorben untuk menyerap zat warna kationik berupa Zat warna pada limbah cair melalui gaya elektrostatis (Bhattacharyya and Gupta, 2008).

Mineral monmorilonit penyusun lempung putih juga memiliki muatan yang bergantung pada $\mathrm{pH}$. Hal ini terdapat pada patahan pinggiran kisi kristal struktur oktahedral monmorilonit penyusun lempung putih (-Al-OH). Pada $\mathrm{pH}$ rendah (kondisi asam), keberadaan proton dari ion $\mathrm{H}^{+}$akan semakin dominan yang mengakibatkan patahan pinggiran kisi kristal pada struktur oktahedral monmorilonit akan mengalami protonasi membentuk $-\mathrm{Al}-\mathrm{OH}_{2}{ }^{+}$. Hal ini tentu akan mengakibatkan semakin kecilnya peluang Zat warna pada limbah cair berinteraksi dengan permukaan mineral monmorilonit penyusun lempung putih. Oleh karenanya, seiring dengan kenaikan $\mathrm{pH}$ kemampuan adsorpsi lempung putih terhadap zat warna Zat warna pada limbah cair bertambah.

Namun pada $\mathrm{pH}$ 2-3 kemampuan adsorpsi dari ketiga jenis adsorben cenderung menurun. Hal ini terjadi karena $\mathrm{pH}$ larutan juga dapat mempengaruhi spesiesi adsorbat. Pada $\mathrm{pH}$ rendah $<4$, Zat warna pada limbah cair cenderung bermuatan positif, namun seiring dengan kenaikan $\mathrm{pH}$, tepatnya pada $\mathrm{pH} \geq 4 \mathrm{Zat}$ warna pada limbah cair cenderung bermuatan ganda ( zwitterionic) (Peng et al., 2013). 


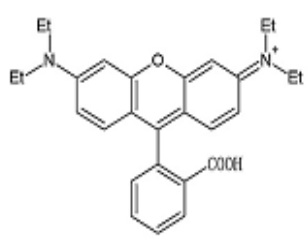

cationic

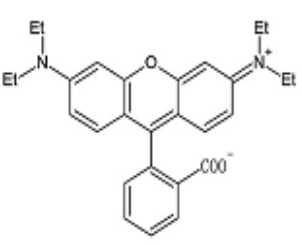

zwitterionic

Gambar 6. Struktur molekul Zat warna pada limbah cair (Peng et al., 2012)

Adanya muatan negatif yang terbentuk pada Zat warna pada limbah cair tentu akan menurunkan interaksi Zat warna pada limbah cair dengan situs aktif mineral monmorilonit penyusun lempung putih. Penurunan interaksi ini terjadi karena adanya gaya tolak menolak yang terjadi antar muatan negatif yang terbentuk pada Zat warna pada limbah cair dengan situs aktif mineral monmorilonit penyusun lempung putih. Hal inilah yang menyebabkan kemampuan adsorpsi pada ketiga jenis adsorben terhadap zat warna pada limbah cair mengalami penurunan pada $\mathrm{pH} \geq 4$.

\section{Kinetika Adsorpsi}

Hasil adsorpsi terhadap pengaruh waktu kontak dapat dilihat pada gambar 7. Berdasarkan gambar 7 teramati bahwa adsorpsi Zat warna pada limbah cair oleh lempung putih tanpa aktivasi (LK-M) optimum terjadi pada waktu kontak 90 menit, lempung putih teraktivasi (LK-A) pada waktu kontak 60 menit dan komposit magnetik lempung putih (LK-K) pada waktu kontak 90 menit .

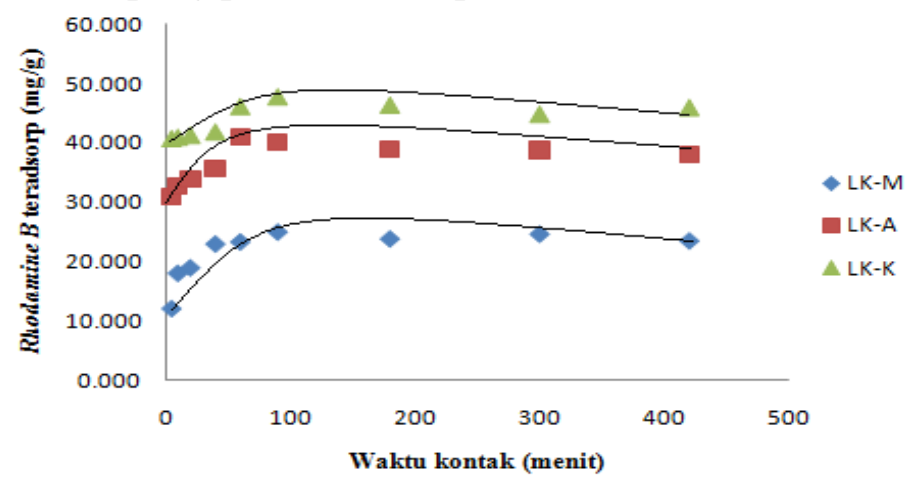

Gambar 7. Grafik hubungan antara waktu adsorpsi dengan jumlah zat warna pada limbah cair teradsorp/gram 
Interaksi ini membutuhkan waktu yang cukup lama untuk mencapai kestabilan ikatan karena Zat warna pada limbah cair memiliki ukuran molekul yang relatif besar sehingga memerlukan waktu untuk mengatur diri agar posisi molekul dapat berinteraksi dan berikatan dengan situs aktif monmorilonit penyusun lempung putih sampai pada akhirnya dapat mencapai kestabilan ikatan.

Sesuai dengan konsep adsorpsi, semakin lama waktu kontak yang diperlukan pada proses adsorpsi antara adsorben dengan zat terlarut maka akan semakin banyak zat yang teradsorpsi, tetapi jumlah zat terlarut yang diadsorpsi akan mencapai nilai batas pada waktu tertentu, yang disebut dengan waktu kesetimbangan adsorpsi dimana adsorben tidak mampu lagi mengadsorpsi karena terjadi kejenuhan pada permukaan adsorben tersebut.

Hasil penelitian, selanjutnya diuji dengan menggunakan model kinetika adsorpsi yang didasarkan pada rumusan kinetika orde satu, kinetika orde satu semu, kinetika orde dua, kinetika orde dua semu, dan kinetika adsorpsi orde tiga. Data yang ditampilkan pada Tabel 2 berikut adalah model kinetika yang dipilih karena cukup mewakili model kinetika proses adsorpsi yang terjadi.

Tabel 2. Parameter kinetika adsorpsi

\begin{tabular}{ccccccc}
\hline & \multicolumn{2}{c}{ Orde satu } & \multicolumn{2}{c}{ Orde satu semu } & \multicolumn{2}{c}{ Orde dua semu } \\
\cline { 2 - 7 } Material & $\mathbf{k}_{\mathbf{1}}$ & $\mathbf{R}^{\mathbf{2}}$ & $\boldsymbol{\beta}$ & $\mathbf{R}^{\mathbf{2}}$ & $\mathbf{k}_{\mathbf{2}}$ & $\mathbf{R}^{\mathbf{2}}$ \\
\cline { 2 - 7 } & (menit $^{\mathbf{- 1}}$ ) & & (menit $^{\mathbf{- 1}}$ ) & & $($ g/mg.menit) & \\
LK-M & 0,0023 & 0,2125 & 0,0246 & 0,876 & 0,1675 & 0,9993 \\
LK-A & 0,0015 & 0,2976 & 0,0174 & 0,9683 & 0,0249 & 0,9995 \\
LK-K & 0,0024 & 0,2054 & 0,0237 & 0,7506 & 0,1340 & 0,9991 \\
\hline
\end{tabular}

Berdasarkan harga koefisien korelasi pada Tabel 2 dapat disimpulkan bahwa adsorpsi Rhodamin $B$ oleh ketiga jenis adsorben mengikuti model kinetika adsorpsi orde dua semu. Model kinetika reaksi ini menunjukan bahwa laju adsorpsi setara dengan kuadrat konsentrasi zat warna Rhodamin $B$ yang diekspresikan dengan $\left(\mathrm{q}_{\mathrm{e}}-\mathrm{q}_{\mathrm{t}}\right)^{2}$.

\section{Kesetimbangan adsorpsi}

Hasil adsorpsi terhadap pengaruh konsentrasi adsorbat kemudian diuji dengan menggunakan model isoterm Langmuir dan Freundlich, sehingga diperoleh data yang ditunjukkan pada Tabel 3.

Bila ditinjau dari nilai koefisien korelasi maka adsorben LK-M dan LK-A mengikuti pola isoterm Langmuir sehingga dapat diasumsikan bahwa situs aktif pada permukaan adsorben bersifat homogen yang berarti bahwa sebuah molekul Zat warna pada limbah cair menempati satu situs aktif dan tidak ada adsorpsi lebih lanjut yang dapat dilakukan pada situs tersebut. Semakin tinggi koefisien korelasi untuk model Langmuir memprediksi bahwa cakupan molekul zat warna pada limbah cair adalah monolayer. Namun, pada adsorben LK-K cenderung mengikuti pola isoterm Freundlich, yaitu pola adsorpsi berlangsung pada 
permukaan heterogen dan membentuk lapisan multilayer, artinya tiap molekul mempunyai potensi penyerapan yang berbeda-beda.

Tabel 3. Konstanta isoterm adsorpsi

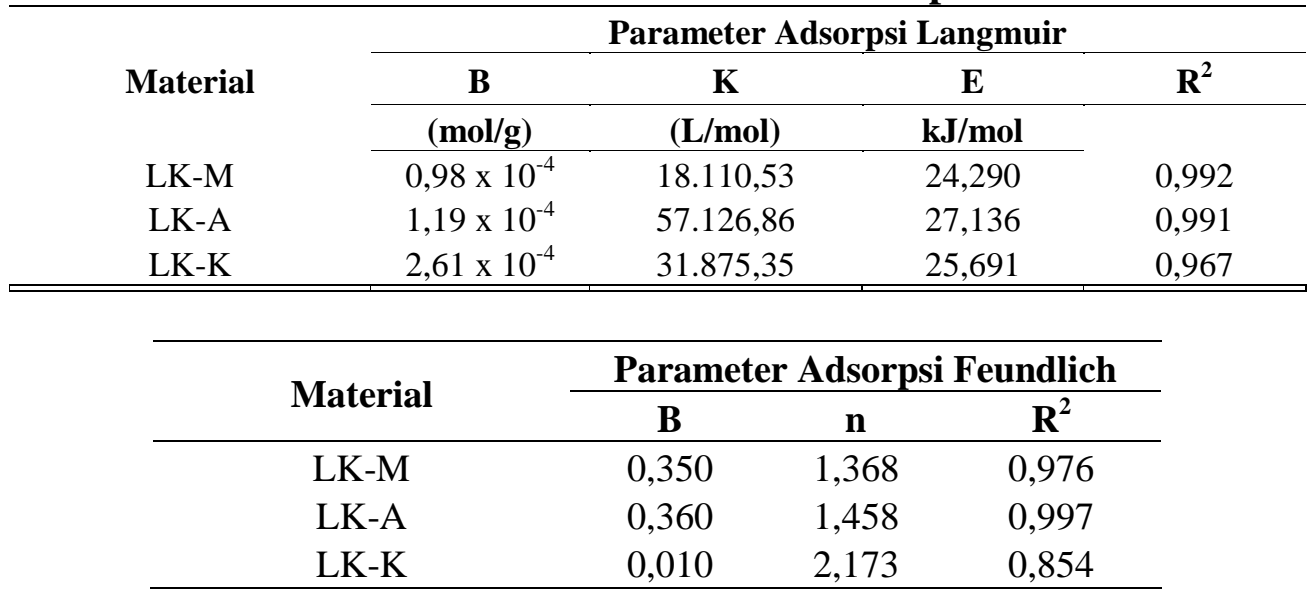

Penerapan persamaan isoterm Langmuir juga dapat dikembangkan untuk menentukan energi adsorpsi menurut persamaan $\mathrm{E}=\mathrm{RT} \ln \mathrm{K}$. Dari hasil perhitungan diperoleh bahwa energi yang diperlukan untuk adsorpsi Zat warna pada limbah cair pada ketiga jenis adsorben $>20 \mathrm{~kJ} / \mathrm{mol}$. Energi yang diperoleh menunjukkan bahwa ikatan yang terjadi antara situs-situs aktif adsorben terhadap Zat warna pada limbah cair merupakan ikatan yang cukup kuat. Menurut Adamson (1990), adsorpsi fisika dan adsorpsi kimia dibedakan berdasarkan energi adsorpsi, reversibilitas dan ketebalan lapisan adsorben. Adsorpsi kimia terjadi bila besarnya energi adsorpsi lebih dari $20 \mathrm{~kJ} / \mathrm{mol}$. Berdasarkan data dari energi adsorpsi maka dapat diasumsikan ketiga jenis adsorben mengikuti pola isoterm Langmuir meskipun nilai $\mathrm{R}^{2}$ pada pola isoterm Freundlich untuk LK-K lebih besar bila dibandingkan dengan pola isoterm Langmuir.

Berdasarkan pola isoterm Langmuir juga dapat ditentukan pula secara langsung nilai kapasitas adsorpsi (B) dari adsorben yang ditunjukan pada Tabel 3. Pada tabel tersebut terlihat bahwa adsorben LK-M, LK-A dan LK-K memiliki kapasitas adsorpsi (B) secara berturut-turut sebesar $0,98 \times 10^{-4} \mathrm{~mol} / \mathrm{g}, 1,19 \times 10^{-4}$ $\mathrm{mol} / \mathrm{g}$ dan $2,61 \times 10^{-4} \mathrm{~mol} / \mathrm{g}$. Dari hasil yang diperoleh menunjukkan bahwa aktivasi dan pengkompositan lempung putih dengan magnetit mampu meningkatkan kemampuan adsorpsinya terhadap zat warna Zat warna pada limbah cair.

Hal ini terjadi karena proses aktivasi mampu melarutkan pengotor sehingga mulut pori dari mineral monmorilonit penyusun lempung putih yang berperan dalam proses adsorpsi menjadi lebih terbuka yang mengakibatkan situs aktif mengalami peningkatan oleh karena situs yang tersembunyi menjadi terbuka. Oleh karenanya, kemampuan adsorpsi lempung putih teraktivasi (LK-A) lebih besar dari lempung putih tanpa aktivasi (LK-M). 
Dari data yang diperoleh diketahui juga bakwa pengkompositan lempung putih dengan magnetit mampu meningkatkan kemampuan adsorpsinya terhadap zat warna Zat warna pada limbah cair sampai dengan dua kali lipatnya. Hal ini terjadi karena adanya peranan dari magnetit yang terkomposit pada lempung putih. Hal ini terjadi karena magnetit memiliki atom $\mathrm{O}$ yang kaya elektron, elektronegativitas tinggi serta bermuatan parsial negatif. Pembentukan ikatan kovalen koordinasi dimungkinkan terjadi karena magnetit memiliki atom $\mathrm{O}$ yang memiliki pasangan elektron bebas yang berperan sebagai basa Lewis dan gugus $=\mathrm{N}^{+}$dari Zat warna pada limbah cair sebagai asam Lewis. Adsorpsi dapat terjadi karena adanya ikatan kovalen koordinasi yakni pada atom $\mathrm{O}$ dari magnetit yang dapat mendonorkan pasangan elektron bebasnya pada gugus $=\mathrm{N}^{+}$yang mempunyai orbital kosong dan kemudian pasangan elektron tersebut dipakai secara bersama. Kemungkinan lain adalah terjadinya interaksi secara ionik antara atom $\mathrm{O}$ yang memiliki elektronegativitas tinggi serta bermuatan parsial negatif dengan zat warna Zat warna pada limbah cair yang bermuatan positif walaupun interaksi yang terjadi tidak terlalu kuat.

\section{Uji Pemisahan Adsorben dalam Larutan Zat warna pada limbah cair}

Uji pemisahan dilakukan pada 0,05 gram adsorben LK-A dan LK-K pada 50 $\mathrm{mL}$ larutan Zat warna pada limbah cair.

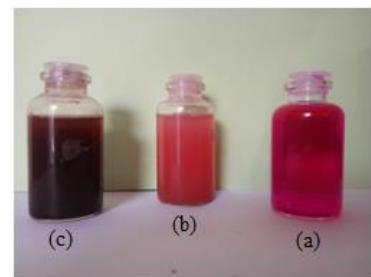

Larutan awal

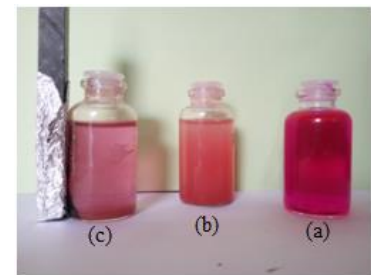

Larutan setelah 2 menit

Gambar 7. Uji pemisahan adsorben (a) Lar. Zat warna pada limbah cair; (b) Lar. Zat warna pada limbah cair + LK-A dan (c) Lar. Zat warna pada limbah cair + LK$\mathbf{K}$

Uji pemisahan dilakukan pada kedua jenis adsorben, yaitu LK-A dan LKK. Setelah digunakan pada proses adsorpsi, fase padat adsorben dipisahkan dari dalam larutan. LK-A dipisahkan dengan proses sedimentasi secara alami oleh gaya gravitasi bumi, sedangkan LK-K menggunakan medan magnet eksternal. Dari gambar 8 terlihat bahwa fase padat LK-K yang memiliki sifat kemagnetan dapat terpisah dari dalam larutan Zat warna pada limbah cair dengan mudah dan cepat menggunakan medan magnet eksternal.

\section{Kesimpulan}

Hasil penelitian menunjukkan bahwa metode kopresipitasi telah berhasil mengkompositkan oksida besi fasa magnetit pada lempung putih asal Kalimantan Tengah dengan nilai magnetisasi sebesar 21,38 emu/g. Uji adsorpsi lempung putih tanpa aktivasi dan komposit magnetik lempung putih terhadap Zat warna pada limbah cair mencapai optimum pada $\mathrm{pH} 3$ sedangkan pada lempung putih 
teraktivasi dan komposit lempung putih optimum masing-masing pada $\mathrm{pH} 3$ dan 2. Kajian kinetika dan kesetimbangan adsorpsi menunjukkan bahwa adsorpsi Zat warna pada limbah cair oleh ketiga jenis adsorben mengikuti kinetika orde dua semu dengan pola isoterm Langmuir.

Penggabungan oksida besi fasa magnetik pada lempung putih asal Kalimantan Tengah mampu meningkatkan kapasitas adsorpsi Zat warna pada limbah cair sampai dengan 2 kali lipatnya dan dapat mempercepat proses pemisahan partikel adsorben dari dalam larutan menggunakan medan magnet eksternal.

\section{Daftar Pustaka}

Ardianto, D., 2013, Sintesis Bentonit Magnetik dengan Metode Presipitasi sebagai Adsorben Ion Logam Berat $\mathrm{Cd}^{2+}$ dan $\mathrm{Co}^{2+}$, Skripsi, Fakultas Matematika dan Ilmu Pengetahuan Alam, Universitas Indonesia : Depok.

Amarullah, D., Margani, Saksono, Priatna, Priono and Sudiro., 2002, Inventarisasi dan Evaluasi Endapan Batubara Kabupaten Barito Selatan Dan Barito Utara Provinsi Kalimantan Tengah, Kolokium Direktorat Inventarisasi Sumber Daya Mineral,(DIM) TA.

Benguella, B and Yacoutas, A., 2007, Adsorption of Benzanyl Red and Nylomine Green from Aqueous Solution by Natural and Acid-Activated Bentonite, Desalination., 235, 276-292.

Bhattacharyya, K. G and Gupta, S. S., 2008, Adsorption of a Few Heavy Metal on Natural and Modified Kaolinite and Montmorillonite : A review, J. Adv. Coll. In. Sci, 140, 114-13.

Elmoubarki, Mahjoubi, Tounsadi, Moustadraf, Abdennouri, Zouhri, 2015, Adsorption of Textile Dyes on Raw and Decanted Moroccan Clays: Kinetics, Equilibrium and Thermodynamics, Water Resources and Industry, 9, 16-29.

Eren, E., Afsin, B and Onal, Y, 2009, Removal of Lead Ions by Acid Activated and Manganese Oxide-Coated Bentonite, J. Hazard. Mater., 161, 677685.

Hajjaji, M and Arfaoui, H., 2009, Adsorption of Methylene Blue and Zink ions on Raw and Acid-Activated Bentonite from Morocco, Appl. Clay. Sci., 46, 418-421.

Hamsah, D., 2007, Pembuatan, Pencirian dan Uji Aplikasi Nanokomposit Berbasis Montmorilonit dan Besi Oksida, Skripsi, FMIPA, Institut Pertanian Bogor, Bogor.

Holtzer, M., Bobrowski, A and Kumon, S., 2011, Temperature Influence on Structural Changes of Foundry Bentonites, J. Molecular. Structure, 1004, 102-108.

Koyuncu, H., 2007, Adsorption Kinetics of 3-Hydroxybenzaldehyde on Native and Activated Bentonite, App. Clay. Sci., 38, 279-287.

Lee, S. J., Jeoung, J. R., Shin, S.C., Kim, J. C and Kim, J. D., 2004, Synthesis and Characterization of Superparamagnetic Maghemite Nanoparticles prepared by Coprecipitation Technique. Magnetism, Magnetic Mater, 282, 147-150. 
Musso, Parolo, Pettinari and Francisca, F., 2014, Cu(II) And Zn(II) Adsorption Capacity of Three Different Clay Liner Materials. Journal of Environmental Management, 146, 50-58.

Notodarmojo, S., 2005, Pencemaran Tanah dan Air Tanah, Bandung : ITB press.

Oliveira, L.C.A., Rios, R.V.R.A., Fabris, J.D., Sapag, K., Garg, V.K. and Lago, R.M., 2003, Clay - Iron Oxide Magnetic Composites for the Adsorption of Contaminants in Water, J. Appl. Clay. Sci., 22, 169-177.

Ortega, E., Ramos and Flores-Cano., 2013, Binary Adsorption of Heavy Metals from Aqueous Solution Onto Natural Clays. Chemical Engineering Journal, 225, 535-546.

Peng, L., Qina, P., Lei, M., Zeng, Q., Song, Q., Yang, J and Gua, J., 2012, Modifying $\mathrm{Fe}_{3} \mathrm{O}_{4}$ Nanoparticles with Humic Acid for Removal of Rhodamine B in Water, J. Hazard. Mater., 209-210, 193-198.

Purwamargapratala, Y., Yusuf, S and Ridwan., 2013, Degradasi Metilin Biru dengan Komposit $\mathrm{TiO}_{2} \mathrm{SiO}_{2} \mathrm{Fe}_{3} \mathrm{O}_{4}$, Seminar Nasional IX SDM Teknologi Nuklir Yogyakarta, ISSN 1978-0176.

Rehman, M., Munir, M., Ashfaq, Rashid, Nazar and Danish, M., 2013. Adsorption of Brilliant Green dye from Aqueous Solution onto Red clay. Chemical Engineering Journal, 228, 54-62.

Saikia, N, J., Bharali, D, J., Sengupta, P and Bornhakun, 2003, Characterication, Beneficiation and Utilization of a Clay from Assam, India, App.Clay Sci., 24, 93-103.

Santos, Rui and Boaventura, 2016, Adsorption of cationic and anionic azo dyes on sepiolite clay: Equilibrium and kinetic studies in batch mode, Journal of Environmental Chemical Engineering, 4, 1473-1483.

Sinta, I, N., Suarya, P and Santi., 2015, Adsorpsi Ion Fosfat oleh Lempung Teraktivasi Asam Sulfat $\left(\mathrm{H}_{2} \mathrm{SO}_{4}\right)$, Jurnal Kimia 9 (2), Juli 2015: 217-225.

Sunardi, Suparno and Yuwono, W., 2011, Adsorpsi Limbah Uranium menggunakan Lempung Nanggulan, Prosiding Seminar Penelitian dan Pengelolaan Perangkat Nuklir, ISSN 1410 - 8178.

Vaclavikova, M., Jagabsky, S., and Hredazk, S., 2003, Magnetit Nanoscale Particles for Removal of Heavy Metal Ions, http/drexxel.edu/coe/research/conference/NATO ASI 2003/ manuscript/ 5.2.vaclavikova.pdf, diakses tanggal 11 April 2014.

Widihati, 2009, Adsorpsi Ion $\mathrm{Pb}^{2+}$ oleh Lempung Terinterkalasi Surfaktan, Jurnal Kimia 3 (1), Januari 2009 : 27-32.

Zhao, Y., Qi, Chena, Q and Zhangb. Behavior of Cr(VI) Removal from

Wastewater by Adsorption onto $\mathrm{HCl}$ Activated Akadama Clay. Journal of the

Taiwan Institute of Chemical Engineers, 50, 190-197. 